\title{
From KRAEPELIN TO KARADZIC: PSyChIATRY'S LONG ROAD TO GENOCIDE
}

\section{ROBERT M KAPLAN AND GARRY WALTER}

...it is always a simple matter to drag people along whether it is a democracy, or a fascist dictatorship, or a parliament, or a communist dictatorship. Voice or no voice, the people can always be brought to the bidding of the leaders. All you have to do it tell them they are being attacked, and denounce the pacifists for lack of patriotism and exposing the country to danger. It works the same for every country. - Herman Göring, Commander-in-Chief of the Luftwaffe, at Nuremberg 1

The twentieth was the century of mass murder, as Niall Ferguson, ${ }^{2}$ Eric Hobsbawm, ${ }^{3}{ }^{4}$ and others have pointed out. The rate of civilian deaths rose from less than 5 per cent before World War I to over 80 per cent by 1980, with women and children a significant majority. The death toll from genocide, mass murder, forced starvation, ethnic cleansing and expulsion exceeded 170 million. In 1990, Michael Burleigh could say that the chance of events such as the Holocaust occurring again were remote; after 11 September 2001, he stated that humankind faced an existential threat to its future. ${ }^{5}$

${ }^{1}$ Gilbert, G M (1947), Nuremberg Diary, New York, Signet.

2 Ferguson, Niall (2006), The War of the World: History's age of hatred, London, Allen Lane.

${ }^{3}$ Hobsbawm, Eric (1994), The Age of Extremes: The short twentieth century 1914-1991, London, Penguin.

${ }^{4}$ Hobsbawm, Eric (1992), Nations and Nationalism since 1780:

Programme, myth, reality, Cambridge, Cambridge University Press.

${ }^{5}$ Burleigh, Michael (2008), Blood E Rage: A cultural history of terrorism, New York, Harper Perennial. Also review by Stuttaford, Andrew (2008), 'Sacred monsters. On Blood \& Rage: A cultural history of 
In a Europe that had been [relatively] peaceful since 1945, the wars that followed the collapse of Yugoslavia in 1990 caused dismay at the rapid rise of extreme nationalism. ${ }^{6}$ Images of gaunt prisoners in Serbian concentration camps between 1992 and 1995 raised the spectre of genocide. Between 150,000 and 250,000 people were killed and a million made homeless. By 1995, when hostilities came to an end following the Dayton Agreement, there were reports of atrocities on all sides-Serbian, Croatian and Muslim Bosnians-but the chief perpetrators were the Serbian Bosnians. Led by Dr Radovan Karadzic, and under the military command of General Ratko Mladic, the Serbs committed genocide to render 70 per cent of the territory of Bosnia free of non-Serbian inhabitants. ${ }^{7}$

Many aspects of the Bosnian genocide were deeply disturbing. But one startling feature emerged - the role of psychiatrists. They were leading figures in the Bosnian Serb political party, the Serb Democratic Reform (SDF). Serbian psychiatrists adopted a public role to promote their nationalist aims, justify the behaviour of the military forces, and denigrate the opposition in psychological terms. The unique spectacle was that of a practising psychiatrist, Dr Radovan Karadzic ${ }^{8}$-in his role as President of Republika Srpska-actively directing the military activities, notably the siege of his home town of Sarajevo.

terrorism by Michael Burleigh', The New Criterion 27, 68, republished 2009 on-line: www.newcriterion.com/articles.cfm/Sacred-monsters3924, accessed 20 March 09.

6 Niebuhr, Robert (2007), 'Yugoslavia: The final showdown', Small Wars \& Insurgencies, September, 18, 3, 380-96.

${ }^{7}$ Cigar, Norman (1995), Genocide in Bosnia: The policy of 'ethnic cleansing', College Station, Texas, Texas A\&M University Press.

${ }^{8}$ Kaplan, Robert M (2003), 'Dr Radovan Karadzic: Psychiatrist, poet, soccer coach and genocidal leader', Australasian Psychiatry, 11, 74-78. 
At this time of writing, Karadzic is on trial before the International Criminal Court in The Hague. His case should shed light on how he used his psychiatric training to devise terror tactics for dealing with the enemy. It may also answer a key question: how does the profession of psychiatry lend itself to such extraordinary state abuse? Decades earlier, in the Nuremberg Doctors' Trial, ${ }^{9}$ it became apparent that the medical profession contained within itself the necessary ingredients for much of its own ruin. And in this regard the psychiatric profession, so often regarded as marginal to the medical mainstream, set the agenda for the rest of the profession [see the Dudley and Gale chapter in this volume].

The path from marginalisation to acceptance in mainstream medicine and the use of modern technology in psychiatry goes back to the early years of the nineteenth century. Psychiatry unerringly allied itself with the dominant social agendas of the day. That the model arose in Germany meant that eugenics, racism and nationalism were allied to an academic approach in which the individual was readily submerged by the doctrine of the greater good of the nation. From Sigmund Freud and Emil Kraepelin, reductionist or vulgarised psychological concepts were used as a tool for ideological pursuits. These tendencies surface recurrently whenever psychiatry becomes involved in abuse of human rights by the nation-state. The terminus of this path, the Bosnian genocide, illustrates this theme.

9 'The doctors' trial', Jewish Virtual library, http://www.jewishvirtuallibrary.org/jsource/Holocaust/doctorstoc html. Accessed 26 November 2011. 


\section{The rise of psychiatry}

Insanity...provides us with the proper scale for comprehending the numerous intellectual, moral, religious, and artistic currents and phenomena of our social life. - Emil Kraepelin 10

Psychiatric illness has been recognised since antiquity. There are credible descriptions of schizophrenia in the Mesopotamian Assyrian Codex. ${ }^{11}$ Until the nineteenth century, psychiatry-its practitioners often referred to as 'mad-doctors' or 'alienists' - was mostly a custodial business, looked down upon by the medical profession and feared by the public. The Enlightenment led to new attitudes. Phillipe Pinel (1745-1826), a fervid revolutionary, believed in an illness model of symptoms and treatment. ${ }^{12}$ The belief that the root cause of mental illness lay in the environment led to more humane psycho-social methods of management in what was known as 'moral treatment'. Pinel's work led to the removal of chains and shackles for the ill, liberation from dungeons, and to the rise of the asylum. Thus began institutionalised psychiatry and the process of organising its practitioners into a professional discipline.

By the second half of the nineteenth century one condition came to dominate and define psychiatry: neurosyphilis,

${ }^{10}$ Decker, H S (2004), 'The psychiatric works of Emil Kraepelin: A many-faceted story of modern medicine', Journal of the History of Neurosciences, 13, 3, 248-76.

${ }^{11}$ Jeste, Dilip, del Carmen, R, Lohr, J B and R J (1985), ‘Did schizophrenia exist before the eighteenth century?', Comprehensive Psychiatry, 26, 6, 493-503.

12 Pinel, Phillipe (1806), A Treatise on Insanity, translated from French by D D Davis, Sheffield, Cadell and Davies.

http:/ / books.google.com.au/books?id=4snWNO11ETAC\&printsec= frontcover\&source $=$ gbs ge_summary $\mathrm{r} \& \mathrm{cad}=0 \# \mathrm{v}=$ onepage $\& \mathrm{q} \& \mathrm{f}=$ false 
known as Generalised Paresis of the Insane, or GPI. Psychiatry had found its grand cause, its defining illness, and it was not until the middle of the twentieth century that GPI ceased to play a part in the daily life of doctors in psychiatric wards. GPI was a uniformly fatal disease that affected men more than women. A middle-class illness, it struck at the heart of the class interests - property. The patient would have a change in personality, a sense of self-importance and an expansive tendency leading to wild spending, investing and drinking. This wrecked the family business and distressed relatives. The victim could ruin the family fortunes, making it 'a disease that had everything to do with property and little to do with sex'. ${ }^{13}$ Patients became demented and unable to care for themselves, often dying in lunatic asylums.

As the twentieth century loomed, the syphilis organism showed its adaptability. Neurosyphilis became, as it were, more egalitarian. Previously an illness of predominantly upper-class men, it went 'down market', affecting women as commonly as men. ${ }^{14}$ Syphilis occupied such a dominating role in the pantheon of diseases that it was accorded 113 pages in the 1893 Index Catalogue of the Surgeon General; tuberculosis, a much more prevalent condition and one with a greater morbidity, was given a mere 55 pages. ${ }^{15}$

Prevalent in all this was an especially malignant idea, namely, hereditary syphilis. First raised in 1595, this was to become a leitmotif of the times. How could a third generation

${ }_{13}$ Shorter, Edward (1997), A History of Psychiatry: From the era of the asylum to the age of Prozac, New York, John Wiley and Sons.

${ }^{14}$ Hare, E H (1959), 'The origin and spread of dementia paralytica', Journal of Mental Sciences, 105, 594-626.

${ }^{15}$ Silverstein, Arthur M and Ruggere, Christine (2006), 'Dr Arthur Conan Doyle and the case of congenital syphilis', Perspectives in Biology and Medicine, 49, 2, 209-19. 
of a family be so afflicted unless the disease was inherited? Arthur Conan Doyle, creator of the fictional Sherlock Holmes, graduated as a doctor in 1881, a period when the Lamarckian theory of acquired characteristics featured prominently in medical education. Doyle chose the topic of complications of tertiary syphilis for his MD thesis. In 1894, his short story 'The Third Generation', illustrated how syphilis could affect several generations of a family, leaving havoc in its wake. ${ }^{16}$

The idea of hereditary syphilis had remarkable persistence. Despite the discoveries of Louis Pasteur and Robert Koch, it endured, fitting perfectly into the theory of degeneration. It coursed through psychiatry like a septic stream into the twentieth century. It attracted an obscure youth living in Vienna. Coming from a rural background rife with intermarriage, mental handicap and ancestor confusion, Adolf Hitler was convinced that hereditary syphilis, 'spread by the Jews', would destroy the German race, his obsession fuelled by persistent rumours that he had a Jewish grandfather. Hitler did not understand the difference between congenital syphilis (the organism can cross the placental barrier, which distinguishes it from other sexually transmitted diseases) and hereditary syphilis. Years later, it was to surface in Mein Kampf where 13 pages were devoted to explaining how the syphilitic taint, (allegedly) spread by Jews, passed down the generations. ${ }^{17}$

In a Europe that was growing in wealth and creating a large bourgeoisie, nationalists seized on middle-class fears of being outbred and losing their privileged status to a surging proletariat. In response, an alliance arose between two

16 Silverstein and Ruggere, op. cit.

${ }^{17}$ Hitler's obsession with syphilis led to inevitable accusations that he suffered the disease. Despite heroic efforts to prove this there is no evidence to support the claim. See Redlich, Fritz (1998), Hitler: Diagnosis of a destructive prophet, New York, Oxford University Press. 
unlikely forces: nationalism (with the Catholic church in close association) and 'respectability'. Nationalism represented an unrepentant swing back to the past, but with significant differences. The cities, hotbeds of liberalism and modernism, encompassed everything that was wrong with the nation. Marginal groups like Jews, Romani and Slavs were perceived as a threat to the social order through their birth rates and their values. They were said to propagate anti-clerical philosophies like abortion, sexual perversion and breakdown of the traditional family unit. The countryside, including regions of appalling backwardness, poverty, ignorance, and devotion to the irrational, was idealised as the völkisch culture which represented a glorious and unsullied past.

The nation was divided along faultlines of race and an extraordinary dichotomy in the private and public life of the individual. State policy ensured a 'polite' society in which sexual activities were directed to childbirth within marriage. Sex began to be regulated for the wellbeing of the greater society. The medical profession duly stepped forward, providing a forensic basis for state regulation. The 'classification' of sex was initiated by psychiatrist Baron Richard von Krafft-Ebing. A believer in the theory of degeneration, he wrote Psychopathia Sexualis, probably the only medical book to have pornographic status. In the process, he gave the world the term 'sado-masochism', but he focused mainly on homosexuality. The state now had the legal basis to prosecute aberrant individuals. 'Perversions' such as masturbation, homosexuality and trans-sexualism were deemed precursors to moral insanity. Krafft-Ebing's book was published in 1886 and by 1871 the German Criminal Code (in its notorious Paragraph 175) had made homosexuality a criminal offence. These outlooks created a breach into which not only Freud but many others surged. The medical profession, including psychiatry through its desire to explain, classify and 'own' many different forms of behaviour, was now in a position to pass judgment on all of 
society, a role that was deeply antipathetic to the ancient and sacred role of treating the individual without fear or favour. To pass from healing the person to the role of healer of society was an opportunity that some could not resist.

\section{Kraepelin and the German eugenics movement}

There are two sorts of psychiatrists, those by inclination, and those by chance; those entering psychiatry by chance are sometimes reasonable. - Emil Kraepelin ${ }^{18}$

An indication of the age is that the three of the most important figures in twentieth century psychiatry were born almost simultaneously - Emil Kraepelin and Sigmund Freud in 1856 and Eugen Bleuler a year later. Compared to the rest of Europe, German psychiatry had a significant advantage. It was practised by academicians who perceived themselves as scientists and saw their patients as research material. ${ }^{19}$

Emil Kraepelin (1856-1926) ${ }^{20}$ qualified in medicine at the University of Leipzig in 1878 and, unusually, wanted to study psychiatry from the start. ${ }^{21}$ His intention was to establish a discipline based on findings that could be proved, abandoning speculative theories from romanticism. Like all psychiatrists of the day, Kraepelin learnt his craft through clinical encounters with syphilis, writing what is probably still the best book on its psychopathology and predicting

18 Boroffka, Alexander (1990), 'Emil Kraepelin (1856-1926)', Transcultural Psychiatry, 27, 228-37.

${ }^{19}$ Engstrom, Eric (2003), Clinical Psychiatry in Imperial Germany: A history of psychiatric practice, Ithaca, New York, Cornell University Press.

20 Shepherd, Michael (1995), 'Kraepelin and modern psychiatry', European Archives of Psychiatry and Clinical Neuroscience, July, 245, 4-5, 189-95.

${ }^{21}$ Meyer, A (1994), 'In memoriam, Emil Kraepelin. 1927', American Journal of Psychiatry, 151, 6 Supplement, 140-43. 
(correctly) that GPI arose from Treponema pallidum infection.

Kraepelin was the organising principal in modern psychiatry. His findings became the paradigm for twentieth century psychiatry. He had deeply bureaucratic instincts, he developed training programs, and constantly lobbied the government for mandatory syphilis testing and alcohol control. ${ }^{22}$ In 1917, he founded the German Institute for Psychiatric Research, a centre that came to dominate psychiatric research.

The eminent psychoanalyst and historian Gregory Zilboorg ${ }^{23}$ described Kraepelin as an 'academic man' who lacked human interest in the individual. He was unreservedly antisemitic, describing Jews as 'a very great danger' to the German 'race' through a tendency to forge ahead. Among the races and classes, he believed that Romani, swindlers, poets and 'psychopathic Jews' were prone to hysteria. ${ }^{24} 25$ Kraepelin's psychiatry was dominated by a somatic or biological perspective in which biographical, social, cultural and psychological dimensions were marginalised. He was the first to apply these terms not solely to individuals but to social groups and institutions. Behaviour that did not correspond with his outlook was attributed to the theory of degeneration. ${ }^{26}$

22 Jablensky, Assen (1995), 'Kraepelin's legacy, paradigm or pitfall for modern psychiatry?', European Archives Psychiatry and Clinical Neuroscience, 245, 4-5, 186-88.

${ }^{23}$ Zilboorg, Gregory (1957), 'Eugen Bleuler and present-day psychiatry', American Journal of Psychiatry, October, 114, 4, $289-98$.

24 Shepherd, op cit, 193.

25 Decker H S (2004), 'The psychiatric works of Emil Kraepelin: a many-faceted story of modern medicine', Journal of the History of the Neurosciences, September, 13, 3, 248-76.

${ }^{26}$ Lomax, Elizabeth (1979), 'Infantile syphilis as an example of 
Preoccupied with the 'will', Kraepelin appeared indifferent to the problems of shell-shocked soldiers or hysterics. ${ }^{27}$

In 1915, psychiatrist Professor Albert Hoche described the end of individualism and the transformation of the nation into a higher organism, the Volk. ${ }^{28}$ Eugenics, arising from the practice of pedigree in veterinary science, became a dominant theme in German medicine and science. Prominent eugenicist Ludwig Woltmann, who drew on Charles Darwin and Comte Arthur de Gobineau for inspiration (with some Karl Marx thrown in for good measure), made race a central concern. ${ }^{29}$ German eugenics was a vulgarised form of Social Darwinism, portraying the struggle for survival in simplistic racial terms, constantly raising the threat to the German people from 'other' groups. Preaching Germanic supremacy, he regarded the struggle for existence as a racial conflict in which Germany would eventually predominate. Three prominent disciples were anthropologists Otto Ammon and Eugen Fischer, the latter then based at the University of Freiburg, and Professor Ludwig Schemann. ${ }^{30}$ Schemann translated and introduced into Germany the Frenchman Comte de Gobineau's four-volume essay on The Inequality of the Human

nineteenth century belief in the inheritance of acquired characteristics', Journal of the History of Medicine and Allied Sciences, January, 34, 1, 23-39.

${ }^{27}$ Kraepelin, Emil (1919), 'Psychiatric observations on contemporary issues', first published in Süddeutsche Monastshefte, June xvi, 2, 17183. Translated by Eric J Engstrom (1992), History of Psychiatry, June, 3, 10, 253-69.

${ }^{28}$ Kaldjian, Lauris (2000), 'Eugenic sterilization and a qualified Nazi analogy: the United States and Germany, 1930-1945', Annals of Internal Medicine, February 15, 132, 4, 312-19.

${ }^{29}$ Weikart, Richard (2003), 'Progress through racial extermination: Social Darwinism, eugenics, and pacifism in Germany, 1860-1918', German Studies Review, May, 26, 2, 273-94.

30 Weikart, op cit 
Races, the doctrine of degeneration and decline and, above all to eager German ears, the 'science' of racial purity.

The trail from the gas chambers and ovens of Auschwitz can be followed back to the hitherto forgotten but first genocide of the century - the Herero and Nama slaughter in German South West Africa (now Namibia) between 1904 and 1906. The first demonstration of the malign consequences of biological racism resulted in the annihilation of over 80 per cent of the Herero nation, the effects of which are still being felt today. ${ }^{31} 32$ This event was largely assisted by the efforts of Eugen Fischer. In 1908 he studied (or rather, he did a series of pseudo-scientific measurements) of 310 children of a mixed race group arising from cohabitation of the settlers and native women in German South West Africa, a people known as the Rehoboth Bastards or Basters. He argued that the physically strong and healthy Basters should initially be allowed to increase in numbers to provide labour to the settlers; thereafter, one should only grant them the minimum protection they needed 'as a race inferior to us' and for as long as these physically strong but mentally inferior mongrelised people were useful. Then nature should take its course through 'free competition, which in [Fischer's] opinion, means [their] demise'.

The Herero genocide was driven by the racial theories of such physical anthropologists. The influence of these men on German medicine, especially psychiatry, was considerable and set the tone for what was to follow. After Germany was defeated and excluded from the colony, the Herero genocide subsided into obscurity [until a decade ago], but its lessons

31 Weikart, op cit, 288.

32 Olusoga, David and Erichsen, Casper (2010), The Kaiser's Holocaust: Germany's forgotten genocide and the colonial roots of Nazism, London, Faber. 
were well learned. The terms Lebensraum [need for living room] and Konzentrationslager [concentration camp] established the pattern of state organisation of genocide by biological means, largely run by doctors. ${ }^{33}$ It is no coincidence that a number of leading Nazis had close connections with German South West Africa and acted as 'conduit' for these concepts. Of these, Herman Göring was the most notorious. ${ }^{34}$

Fisher's study, published in Germany in 1913, must be regarded as one of the precursors of the Holocaust. In 1919, Entente troops, mostly French, occupied the Rhineland. Children born out of wedlock (known as Rhineland Bastards) arose from relations between local women and the soldiers. After 1937, Fisher created a medical unit, Commission Number 3, to secretly sterilise 400 children of 'Rhineland Bastards'. In 1927, Fischer became Director of the new Kaiser Wilhelm Institute for Anthropology, Human Heredity, and Eugenics in Berlin, supervising academics who became leading figures in providing justification for Nazi antisemitism and developing laws which then excluded Jews, Rom people and other 'non-Aryans' from German citizenship. By training SS doctors and medical students in eugenics and racial hygiene, he supported physicians directly involved in mass murder and crimes against humanity. Fischer used his scientific authority to justify colonial exploitation and racial extermination. His disciples were equally influential in anthropology, sociology, medicine and eugenics. Fritz Lenz became the first professor of 'Race Hygiene' at the University of Munich in 1923. Setting the tone for the medical involvement in genocide, in a 1917 article Lenz, Fischer's close colleague, proposed putting the interests of one's race above

${ }^{33}$ Madley, Benjamin (2005), 'From Africa to Auschwitz: How German South West Africa incubated ideas and methods adopted and developed by the Nazis in Eastern Europe', European History Quarterly, 35, 3, 429-64.

34 Madley, op cit, 450. 
all ethical considerations.

To what extent psychiatrists were the driving force in devising biological solutions to racial 'problems', or were easily encouraged to do so, ${ }^{35}$ may be debatable, but there can be little doubt about their enthusiasm to become involved. In the lead-up to World War I, eugenics as the dominant paradigm flourished in Germany, America, Great Britain, Sweden and elsewhere, with Fischer at one point hailed as heading an international eugenics organisation. Eugenics had a considerable influence on research, planning and the quest for effective treatments. Other influences were also beginning to establish themselves, notably the rise of psychoanalysis. Initially concerned with establishing his movement, Freud's testimony to the commission of inquiry on war neurosis led to growing interest. In the decades before his death, Freud began to stray from strictly technical issues, writing instead about the application of psychoanalysis to the condition of humanity as a whole. Reacting to the rise of fascism, Freud came to hold a pessimistic view of human nature as dominated by the death instinct. Religion was merely an illusion. He was not alone in this: Kraepelin wrote about Bismarck, describing Weimar republican society as hysterical and the socialist leaders as psychopathic. Yet soon the medical profession itself came to be caught up in horrific abuse and widespread death in the Armenian genocide. That genocide and its biological thrusts set the stage for what was to be the precursor to the Holocaust.

\section{Doctors and the Armenian Genocide}

If a physician presumes to take into consideration in his work

35 Friedlander, Henry (1995), The Origins of Nazi Genocide: From euthanasia to the final solution, Chapel Hill, University of North Carolina Press. 
whether a life has value or not, the consequences are boundless and the physician becomes the most dangerous man in the state. - Christopher Willhelm Hufeland ${ }^{36}$

The 1914-1923 Armenian, Pontian Greek and Assyrian genocide was in so many ways the template for the Holocaust: forced emigration, expulsions, property confiscations, forced labour, public torture and executions, medical experiments, elementary gassings, starvation, and death marches. It was largely directed and carried out by doctors, leading members of the Ittihadist Party who came to power in a coup in $1908 .{ }^{37}$ Dr Behaeddin Sakir and Dr Mehmett Nazim, held responsible in part for the deaths of at least 1.5 million Armenians, 350,000 Pontian Greeks and perhaps 250,000 Assyrian Christians, played a pivotal role in the establishment and deployment of the Special Organisation units, extermination squads staffed by violent criminals released from prisons to undertake killings. Sakir had worked as chief physician of Soloniki Municipal Hospital and Nazim, described as 'a doctor by profession and not without promise', in what must be regarded as one of the most misguided appointments in the history of medicine, was designated Professor of Legal (Ethical) Medicine at Istanbul Medical School.

Many of their collaborators, mostly governors of the Anatolian provinces where the Armenians lived, were graduates of the Imperial Medical School. Medical personnel did not merely supervise proceedings but were directly involved in the killings, often participating in torture. Dr Mehmed Reşid, known as the 'Executioner Governor', was

${ }^{36}$ Haas, François (2008), 'German science and black racism - roots of the Nazi Holocaust', Federation of American Societies for Experimental Biology Journal, February, 22, 2, 332-37.

37 Dadrian, Vahakn (1986), 'The role of Turkish physicians in the World War I genocide of Ottoman Armenians', Holocaust and Genocide Studies, 1, 2, 169-92. 
extraordinarily brutal, smashing skulls, nailing red-hot horseshoes to victims' chests, and crucifying people on makeshift crosses. Sadistic cruelty was demonstrated by ophthalmologists who gave eye drops to children that made them blind and who performed unnecessary, deliberately disfiguring ophthalmological procedures, especially on young girls. ${ }^{38}$ Other doctors, describing their victims as subhuman, used them as guinea pigs to infect a range of diseases. Hundreds of victims were injected with blood from typhus cases.

Dr Ali Said was accused of killing thousands of infants, adults and pregnant women by administering poison as liquid medicine. He ordered the drowning at sea of patients who refused the 'medicine' and directed the disposal of their corpses. Infant victims of Dr Tevfik Rusdü were taken to a purported steam bath and killed with a toxic gas, an ominous precursor to the later Judeocide.

The later Kemalist government turned its back on the issue and the collective (and aggressive) Turkish denial that the genocide had ever occurred took hold. In the years afterwards, looking at the issue from radically different moral standpoints, both Hitler and Churchill noted that everyone [wilfully] forgot the matter before long and Armenia was destined to slip into the West's historical amnesia [at least until the 1980s].

Dr Mehmed Reşid's suicide note summed up the attitude of these medical genocidaires:

Even though I am a physician, I cannot ignore my nationhood. Armenian traitors...were dangerous microbes. Isn't it the duty of a doctor to destroy these microbes? My

38 Dadrian, Vahakn (2003), 'Children as victims of genocide: the Armenian case', Journal of Genocide Research, 5, 3, 421-37. 
Turkishness prevailed over my medical calling. Of course my conscience is bothering me, but I couldn't see my country disappearing. As to historical responsibility, I couldn't care less what historians of other nations write about me. ${ }^{39}$

The Armenian genocide set the groundwork for the most notorious examples of medical complicity in state abuses: the Nazi doctors who participated in euthanasia and genocide, and the Japanese doctors who practiced biological warfare. Included among the former were psychiatrists, who, in carrying out Hitler's euthanasia program on their patients, appear to have been in a state of complete moral disarray.

\section{Racial psychiatry, sterilisation and the Holocaust}

[Hitler] could, if need be, do without lawyers, engineers, and builders, but not without medical professionals, suggesting in an early speech before the National Socialists Physicians' League...'you, you Nationalist Socialist doctors, I cannot do without you for a single day, not a single hour. If ...you fail me, then all is lost. For what good are our struggles, if the health of our people is in danger?' --Adolf Hitlert0

Many members of the German medical profession needed no pushing to accept Nazi ideology after Hitler came to power in 1933. Doctors were the first profession to join and embrace the Nazi party and had the largest representation of all occupational groups; ${ }^{41}$ of 15,000 Nazi Party medical members, 3,000 were psychiatrists. Nazi racial theories were accepted without question. The profession acquiesced in the drive to expel all Jewish doctors. The Nazi physician was designated a 'selector' to improve the health of the nation by removing

39 Baron, J H (1999), 'Genocidal doctors', Journal of the Royal Society of Social Medicine, 92, 11, 590-93.

${ }^{40}$ Haas, op cit, 332.

${ }^{41}$ Kater, Michael H (2000), Doctors under Hitler, Chapel Hill, NC, The University of North Carolina Press. 
'inferiors' ${ }^{42}$ Eugenics and racial hygiene were compulsory subjects in medical schools. This enthusiasm was not restricted to Germany. Following the Anschluss, Austrian physicians forced Jewish doctors out of the Vienna Faculty of Medicine, which more than any other European university had a huge Jewish presence-78 per cent of the staff, including some Nobel Prize winners.

The role of psychiatrists in mass murder began in 1938 with their prominent involvement in the sterilisation of patients said to have incurable physical or mental disease. The process soon accelerated with the move to exterminate psychiatric patients. In 1928, jurisprudence professor Karl Binding and psychiatrist Albert Hoche enunciated their concept of 'life unworthy of life', which quickly became the raison d'etre of the Nazi biological vision. The 'Aktion T4 program' to kill 'unworthy' adults on eugenic grounds was based at six centres in Germany and Austria. Under the sign of the Red Cross, gas chambers were introduced to dispose of 'incurables' from the mental hospitals of the Reich. Psychiatrists experimented with killing by phenol injections and carbon monoxide gassing. Tiergartenstrasse 4 was the address at which the Auschwitz, Belzec, Treblinka, Majdanek and Sobibor gas chambers had their first trial run.

No coercion was involved. Resistance to participation in these activities was very limited. Opposition to the T4 philosophy came from men like Bishop Clemens von Galen, Karl Bonhoeffer, Oswald Bumke and Gottfried Ewald. John Rittmeister, a Swiss-trained psychoanalyst and Communist had been involved in underground activities to oppose the Nazis, ostensibly spying for America; he was the only

42 Proctor, Robert (2000), 'Nazi science and Nazi medical ethics: some myths and misconceptions', Perspectives in Biology and Medicine, Spring, 43, 3, 335-46. 
psychiatrist to be executed-by beheading in May 1943.43 Ernst Kretzmer made the observation that whereas in the past they had treated psychopaths, they were now ruled by them - and was lucky to get away with his life. Paul-Gerhard Braune, who was arrested, wrote to Hitler condemning the very concept of 'life unworthy of life', warning that the moral foundations of the nation would be undermined.

There was no shortage of supporters of the euthanasia program. The leading figure, Ernest Rüdin, was followed by professors Heyde, Carl Schneider, de Crinis and Nitsche. Carl Jung's enthusiasm for Nazism went well beyond mere flirtation but he managed to cover his tracks after the war. There were at least 275,000 victims of this 'cleansing' program. Schneider's eagerness included grandiose plans for a vast research institute to study genetic aspects of idiocy and, while it never materialised, he did experimental work on brains from euthanased patients. ${ }^{44}$

German doctors unquestioningly shared the values of Wilhelmine Germany. The loss of World War I came as a shattering blow, followed by the Weimar Republic, a regime they rejected. There was also a practical issue: loss of income. Following the Depression, health funding was significantly reduced and medical schools were producing far more graduates than the system could absorb, a situation only remedied by Hitler's ascent to power in 1933. That the mass clearing of all Jewish doctors from practice would inevitably lead to an improvement also featured in the doctors' thinking. ${ }^{45}$ From 1927 to 1932, the average annual income of

${ }^{43}$ Hunter, Ernest (1993), 'The snake on the caduceus: dimensions of medical and psychiatric responsibility in the Third Reich', Australian and New Zealand Journal of Psychiatry, March, 27, 1, 149-56.

${ }^{44}$ Lifton, Robert J (1986), The Nazi Doctors: Medical killing and the psychology of genocide, New York, Basic Books, 123.

45 Biddiss, M (1997), 'Disease and dictatorship: the case of Hitler's 
doctors fell by 27 per cent; by 1935 it had increased by 25 per cent. ${ }^{46}$

The central concept in Nazi ideology was the 'symbolisation of immortality'. Fritz Lenz (and later Rudolf Hess) would suggest that National Socialism was nothing but applied biology. ${ }^{47}$ The German medical profession was designated the 'central intellectual resource' of the New Order. ${ }^{48}$ In this grotesquely thaumaturgic vision, the doctor was the final agent in the Nazi myth of therapy by mass murder. Seduced by the power of utilitarian thought and arguments, German doctors allied their professional skills with the annihilating process of a despotic government. Echoing Turkey's Dr Mehmed Resid, Fritz Klein, a Nazi doctor, explained to author Robert Jay Lifton that he 'killed in order to cure ${ }^{149}$, and that made him a good doctor. Their statements at Nuremberg indicated how they lost their moral bearings in this grotesque Nazi political culture. ${ }^{50}$

During World War II, doctors made 'selections' at the death camps, dividing victims into those destined for immediate extermination in the gas chambers and those who

Reich', Journal of the Royal Society of Medicine, June, 90, 6, 342-46. ${ }^{46}$ Sofair and Kaldjian, op cit

47 Baur, E, Fisher, E and Lenz, F (1931), Menschliche Auslese und Rassenhygiene (Human Selection and Race Hygiene), Munich, Lehmanns, 417. Baur, E, Fischer, E and Lenz, F (1931), On Human Heredity, translated by Eden \& Cedar Paul, New York, Macmillan Co. 48 Proctor, Robert (2000), 'Nazi science and Nazi medical ethics: some myths and misconceptions', Perspectives in Biology and Medicine, Spring, 43, 3, 335-46.

${ }^{49}$ Lifton, op cit

50 'Extracts from final statements of defendants', in Spitz, Vivien (2005), Doctors from Hell: Accounts of Nazi experiments on humans, Boulder, CO, Sentient Publications, 258-62. 
could do some useful work or could be used in experiments. The operation of the crematoria, determination of when the victims were dead and choice of means of killing were done under medical supervision.

Psychiatric euthanasia centres served as training institutions for SS doctors who went on to construct the death camps. These doctors had seven times the membership of the SS compared to other sectors of the German population. ${ }^{51} \mathrm{No}$ coercion was required to get doctors to work in experimental institutes or concentration camps and there was no shortage of volunteers. Large-scale experimental programs were conducted by leading medical research institutes using untermenschen, 'sub-human' subjects, from concentration camps. The only physician to command a death camp (Treblinka) was psychiatrist Dr Imfried Eberl. ${ }^{52}$

The Nuremberg Doctors Trials in 1946 proved everything-and nothing. ${ }^{53}$ They revealed the role of doctors in experimenting on human subjects and in running death camps. The doctors, to a man, lacked any contrition, stating that they were doing no more than following state policy and their experiments were all done for 'the greater good'. It is perhaps problematic that the trial focus was arguably on details of warped experimentation rather than the doctors' role in industrialised mass murder.

The Nuremberg Code established criteria to ensure that the abuse of human beings for experimentation would not

51 Zwi, Anthony (1987), 'The political abuse of medicine and the challenge of opposing it', Social Science and Medicine, 25, 6, 649-57. 52 Strous, Rael D (2006), 'Nazi euthanasia of the mentally ill at Hadamar', American Journal of Psychiatry, January, 163, 1, 27. ${ }^{53}$ Marrus, Michael (1999), 'The Nuremberg Doctors' Trial in historical context', Bulletin of the History of Medicine, 73, 1, 106-23. 
occur again. ${ }^{54}$ Alone of German institutions, the medical profession escaped denazification. No attempt was made to acknowledge the abuses - let alone even atone for them - and this continued until well into the 1970s when intense (and foreign) exposure forced some concessions.

\section{Medical abuse after 1945 - a growth industry}

There is nothing in the human being that which cannot be verbalised... What a person hides from himself, he hides from society. There is nothing in Soviet society that is not expressed in words. There are no naked thoughts. The unconscious does not exist because it is not available for the conscious control. - Joseph Stalin 55

By the time of Hitler, the distinction between civilian and military combatants was blurred beyond recognition; atrocities against the civilian population were regarded as an essential means of waging war. Murder of civilians was a feature of World War II; in Yugoslavia, for example, more civilians had been killed by Chetnik and Ustasa resistance forces than by the Nazi invaders.

What happened in mid-Europe mid-century gave birth to the shibboleth 'Never Again!'. The Holocaust, the Nuremberg and 110,000 other trials that ensued, and the 1948 Convention on the Prevention and Punishment of Genocide led to this universal cry. But it wasn't long before we had to witness genocide yet again in most continents and in diverse domains: the Soviet deportations of whole nations, the Indonesian

54 (1996), 'The Nuremberg Code (1947)', British Medical Journal, 3131448.1, DOI 10.1136/bmj.313.7070.1448. Available from http://www.bmj.com/content/313/7070/1448.1.full 55 Korolenko, Caesar and Kensin, Dennis (2002), 'Reflections on the past and present state of Russian psychiatry', Anthropology and Medicine, 9, 51-64. 
massacres, genocide in East Timor, Burundi, Rwanda, the Chittagong Hill Tribes, the massive death tolls in establishing first Pakistan, then Bangladesh. Amidst such carnage, there was the spectre of Soviet psychiatry distorting every ethical precept of the profession in its role as a slavish agent of the Soviet regime. If people began to think that postwar genocide was by now essentially the province of Africa and Asia, they were wrong. A nightmare in the Hitlerian mould was awaiting in what was Yugoslavia.

\section{The origins of Yugoslavian medicine and psychiatry}

At a time when Germany can expel tens of thousands of Jews and Russia can shift millions of people from one part of the continent to another, the shifting of a few hundred thousand Albanians will not lead to the outbreak of a world war. Vaso Cubrilovic, predicting ethnic cleansing 56

Information on the origin and development of Yugoslavian psychiatry and psychology is almost nonexistent in the English literature, and scarce enough in Serbo-Croatian journals, ${ }^{57} 58$ but certain conclusions can be drawn. Following the Enlightenment, Croatian and Latinist writers made contributions to psychology - Croatian philosopher Marko Marulic (1450-1542) is credited with first using the term 'psychology',59 but it took until 1920 before psychology had an academic place in universities.

Yugoslavian psychiatry, like the rest of Europe, drew

56 Weine, Stevan (1999), When History is a Nightmare: Lives and memories of ethnic cleansing in Bosnia-Herzegovina, Rutgers University Press, London, 87.

57 Kline, Nathan S (1963), 'Psychiatry in Yugoslavia', Psychiatric Quarterly, April, 37, 245-52.

58 Starjevic, V, personal communication.

${ }^{59}$ Marinkovic, Ksenja (1992), 'The history of psychology in former Yugoslavia: An overview', Journal of the History of the Behavioral Sciences, 28(4), 340-51. 
heavily on the German School, with its emphasis on Kraepelinian dualism, biological factors and eugenics. Psychoanalysis had a natural attraction to some individuals when Vienna, where Freud was based, and the regions that became Yugoslavia, were still in the Austro -Hungarian Dual Monarchy. Following World War II, at least in the first few years, the Communist federated state that appeared under Marshall Tito was determined to be more ideologically pure than Stalinist Russia. Yugoslavian psychiatry changed when psychological testing and psychoanalysis were seen as politically unacceptable bourgeois indulgences. The emphasis was on Pavlovian behaviourism, with the addition of biological treatment. Within a decade, ideological restrictions were relaxed.

Despite rigid centralisation of control, psychiatric services varied between the component states and this tended to influence the approaches taken. The influence of Communism was regarded as stronger and lasted longer in Serbia than in Croatia and Slovenia. The result was a greater emphasis on a clinical and more 'person-orientated' psychology in Belgrade, while there was greater production of academic researchbased work in Zagreb. Possibly because of its long-standing ties to the Germanic world, Zagreb was the most wellendowed centre, while Belgrade tended to attract those who were psychoanalytically orientated. ${ }^{60}$ There was nothing unusual about this: even in Nazi Germany, where Freud was considered anathema, a form of analytic psychotherapy continued at the Göring Institute for the duration World War II. After 1970, Yugoslavian psychiatrists would regularly attend international conferences and train at other centres, such as the Tavistock Institute or the Maudsley Hospital in London.

${ }^{60}$ Kline, op cit 


\section{Psychiatrists and the Bosnian genocide}

These are truly scenes from hell, written on the darkest pages of human history. - Judge Fouad Riad (1995), reviewing the Srebrenica killings 61

The 1992-1995 Bosnian war arose from the break-up of the nation state called Yugoslavia. Following the death of Tito and the fall of Communism, multi-ethnic Yugoslavia was doomed. Slovenia, after a brief clash with Croatia, was the first to secede. Transforming seamlessly from their role as Communist apparatchiks to nationalist leaders, Franjo Tudjman (Croatia) and Slobodan Milosevic (Serbia) were determined to expand their territories by expelling other ethnic groups. Playing on ancient scores, the two states went to war in 1991, with atrocities on both sides. While both made gains, the outcome was less than satisfactory for Milosevic, who then set his sights on the multi-ethnic state of BosniaHerzegovina as his prime goal. ${ }^{62}$ Milosevic used the Serbian Democratic Party of Bosnia-Herzegovina (SDS) as a proxy for his goal of creating a Greater Serbia.

An ominous phrase entered the lexicon: 'ethnic cleansing', the use of brutal force to remove Muslims from territories claimed by the Serbs. Harking back to the atrocities of the Croatian Ustasa during World War II, it has the same meaning and intent as clearing Europe of its Jews, Judenrein. Ethnic cleansing involved individual and mass killing, arbitrary extrajudicial killings, mass rape, starvation, destruction of residences, property and religious institutions, and population expulsion. ${ }^{63}$ It was first used by Slobodan

61

http://www.guardian.co.uk/world/2005/jul/12/warcrimes.iantray nor/print, retrieved 24 Nov 2011

62 Markusen, Eric (2003), 'Genocide in former Yugoslavia, 1992-1995', Journal of Genocide Research, December, 5, 4, 605-15.

63 Blum, Rony, Stanton, G H, Sagi S, and Richter, E D (2008),'"Ethnic 
Milosevic in April 1987 to describe Albanian violence towards the Kosovar Serbs. The term was then used by the media from July 1991 and by the United Nations in 1993; recent examples of the practice and its underpinnings have been thoroughly examined in Norman Naimark's book, Fires of Hatred. ${ }^{64}$

Serbian psychiatrists were prominent in nationalist politics. The SDS, including many of its medical members, was established in 1990 by Zagreb-based psychiatrist Dr Jovan Raskovic. ${ }^{65} \mathrm{He}$ was born in Knin in 1929. With the onset of war, his family moved to Zagreb. He studied medicine at the University of Zagreb, qualifying in 1956. He obtained his psychiatric degree in 1962 and worked in the neuropsychiatric ward at Sibenik Hospital. A well-known psychiatric figure in Yugoslavia, he published widely in international psychiatric journals. His early papers on social and cultural topics give little indication of his political views. Later books (Narcissism and Depersonalisation, 1990) were more explicit, and the most notorious was Luda Zemlja (The Mad Country, 1990). ${ }^{66}$ Raskovic wrote that Catholics (Croats), Orthodox (Serbs) and Muslims experienced different neuroses: Serbs were strongly oedipal, Croats fearful of castration and Muslims anally fixated. ${ }^{67}$ On this premise, Croats were psychologically driven to challenge the power of Serbs, the 'nation of tragic destiny'. The connection between heaven and national destiny created 'conditions for the religious destiny of an ethnical being'. As a

cleansing" bleaches the atrocities of genocide', European Journal of Public Health, April, 18, 2, 204-09.

${ }^{64}$ Naimark, Norman (2001), Fires of Hatred: Ethnic cleansing in twentieth-century Europe, Cambridge, Mass, Harvard University Press.

65 Weine, op cit, 91-93.

66 Weine, op cit, 92.

${ }^{67}$ Weine, op cit, 91. 
result of 'laws regarding the hygiene of the anal channel', Muslims were disposed to gather property and behave aggressively. In this fashion, Raskovic used psychoanalytic jargon to justify Serbian aggression, while simultaneously dehumanising the Muslim opposition. He claimed ${ }^{68}$ that his conclusions were derived from decades of psychiatric work at the borders of the three republics.

Raskovic addressed public meetings. He refused to join Tudjman's government because the latter would not acknowledge Serbian rights. Tudjman made public a taperecording in which Raskovic derided Serbians, forcing Raskovic to stand down. He retired to Belgrade and from any further involvement in politics.

In 1989, an obscure Sarajevo-based psychiatrist, Dr Radovan Karadzic, became head of the Serbian Green Party (a grim irony in view of his later despoiling of large tracts of Bosnia). The following year he surprised many by replacing Raskovic as head of the SDS. He immediately adopted a posture of aggressive nationalism and vicious anti-Muslim rhetoric, confusing many who had regarded him as unscrupulous but apolitical until then. The SDS proclaimed a network of 'Serb Autonomous Regions' which ${ }^{69}$ from 1992 orchestrated the removal of all Muslims and Croats in the Serbs' path. After a strong vote in the November 1990 elections, the SDS participated in a tri-national Bosnian government under President Alija Izetbegovic. As Yugoslavia moved toward dissolution in the following year, Karadzic warned that if Bosnia and Herzegovina declared independence, Bosnian Serbs would secede and seek union with Serbia. After the republic's electorate voted for independence, war erupted in April 1992.

68 Weine, op cit, 99.

${ }^{69}$ Gow, James (2003), The Serbian Project and its Adversaries: A strategy of war crimes, London, C Hurst and Co. 
Karadzic became president of the Bosnian Serb Republic (Republika Srpska) based in the self-proclaimed capital of Palé. By December 1992, Bosnian Serbs had seized about 70 per cent of Bosnia and Herzegovina. In the course of the conflict, Serb forces committed many atrocities, chiefly against Muslims. Tactics included mass execution, the establishment of rape centres, torture, and forcible removal of people. Concentration camps, not seen in Europe since the Nazi era, were re-established. Karadzic authorised the siege of Sarajevo, shelling the homes of his colleagues and killing patients in their beds at the hospital where he had worked until recently ${ }^{70}$.

Sydney psychiatrist Dusan Kecmanovic, who had direct experience of the events that led to the post-Yugoslavia wars, described the behaviour of psychiatrists at the time as 'ethnonationalism' - defined as the absolute precedence of loyalty to one's own ethno-national group. ${ }^{71}$ This was characterised by preferential treatment of patients of the same ethnicity, the disproportionately high numbers of psychiatrists among the political leadership, and the involvement in ethno-nationalist studies or statements beyond usual professional interests. These criteria applied to the ethno-psychological writings of both the Croatian and Serbian psychiatrists of the period. Each side used psychoanalytic vocabulary to rationalise the defects of their enemies.

In 1993, Serbian psychiatrists published The Stresses of War-in collaboration with government departments-

${ }^{70}$ Kaplan, op cit

71 Kecmanovic, Dunsan (1999), 'Psychiatrists in times of ethnonationalism', Australian and New Zealand Journal of Psychiatry, June, 33, 3, 309-15. 
documenting the effects of the war on the Serbian people. ${ }^{72}$ The book alleged that the international media 'satanised' the Serbian people, preparing the way for genocide against them. While condemning war crimes and genocide, the authors' bias was evident in their discussion of the rape of non-Serb women. First, they claimed that the number of victims was greatly understated; second, the tendentious allegation was posited that rapes could not have been ordered by officers because soldiers cannot get erections on command. In an ironic reversal of Dr Raskovic's writings, the psychiatrists alleged that psychiatry was being misused to 'spread hatred against the Serbian people', and in their subsequent book, Sanctions (1994), ${ }^{73}$ it was suggested that growing international sanctions acted as a prelude to Serbian genocide.

Professor E Klein of Zagreb University wrote that Serbs were militant, had a warrior culture and tended to form groups around warrior-leaders. They often had an inferiority complex because of their 'lower level of civilisation and culture' ${ }^{74}$ Professor M Jakovljevic, at the same institution, said Serbs had a paranoid political culture manifesting in an 'almost erotic attitude' towards weapons, producing a nihilistic destructiveness. This compared adversely with the Croatian political culture of peaceful co-existence. ${ }^{75}$

Professor J Maric, at Belgrade University, took a different tack. Serbs, he stated, were well-intended, peaceful and did not 'denigrate other peoples'. ${ }^{76}$ Maric contends that while

72 Weine, op cit, 133-46.

${ }^{73}$ Kaličanin, Predrag (1994), The Stresses of War and Sanctions, Belgrade Institute for Mental Health.

${ }^{74}$ Kecmanović, Dusan (2002), Ethnic Times: Exploring ethnonationalism in the former Yugoslavia, Westport, CT Praeger Publishers, 147.

${ }^{75}$ Kecmanović, ibid.

${ }^{76}$ Kecmanović, Dusan (2002), Ethnic Times: Exploring ethnonationalism in the former Yugoslavia, Westport, CT, Praeger Publishers, 148. 
they did not have high level of material wellbeing, they did not subscribe to the superficial politeness found in the West. Serbian psychiatrists, while ostensibly presenting their case in a balanced and objective fashion, were both publicising the Serbian case and seeking to justify ethnic cleansing practices in the Bosnian war. By ignoring the aggressive role of the Serbian government, these psychiatrists acted, in effect, as genocide apologists.

Milosevic signed the Dayton peace accord on December 1995, effectively shutting the door on the Bosnian Serb leadership. The accord partitioned Bosnia and Herzegovina into Serb and Muslim-Croat areas and ended the war. The political tide turned and many Bosnian Serbs held Karadzic responsible for their isolation. ${ }^{77}$ In 1995, Karadzic was indicted by an international War Crimes Tribunal for the massacre of Muslim and Croatian civilians. He resigned in July 1996, swearing he would never stand trial. After the fall of Milosevic, he went underground in Serbia. There he remained, protected by a network of Serbian loyalists until his arrest in 2008.

\section{Radovan Karadzic - a psychiatrist's own story ${ }^{78}$}

Why not? It's all strange here, nothing is normal. Psychiatrist Dr Ferhid Mujanovic, after Kosovo Hospital was shelled by the Serbians.

At 15, Radovan Karadzic moved to student quarters in the city of Sarajevo, living in a multi-ethnic neighbourhood and mixing comfortably with Serbian, Croatian and Muslim neighbours. The young Karadzic was described as naïve, but

77

http://www.bosnet.org/archive/bosnet.w3archive/9709/msg00036 .html.

${ }^{78}$ Weine, op cit, 106-32. 
endearing. Neighbours recalled a shy farm boy wearing a grimy white pullover knitted with wool from his village. ${ }^{79}$ Later, his striking looks - he was over six foot tall with a Byronic shock of hair - attracted attention, and he became a serial seducer of women. In 1965, Karadzic, with a high school diploma from the medical vocational school, ${ }^{80}$ studied at the University of Sarajevo. He received his medical degree on 19 July 1971 and then qualified in psychiatry.

During this time, Karadzic had joined and left the Communist Party, became involved in student politics and dabbled in literary circles. He wrote four volumes of poetry which he recited in public, accompanied by the gusle (a onestringed Serbian instrument), to indifferent response. Karadzic had no doubt about his talent as a poet, but the literary circles with whom he associated were dubious, regarding him as little more than a dabbling amateur. This did not deter him. He published several volumes of his work, receiving state-funded prizes for his efforts. He also wrote children's stories and composed Serbian folk music, which he performed on radio. 81

Analysis of his early poetry reveals prophetic, if not apocalyptic, visions of the future. ${ }^{82}$ In 1971, 21 years before the war, he wrote a poem called 'Let's go down to the town and kill some scum'. Another poem of that time, 'Sarajevo', speaks of the city burning in a 'blood-soaked tide'. His fourth volume, published in 1990, reveals an obsession with

79 Wilkinson, Tracey (1995), ‘Bosnians recall Karadzic, a neighbor turned enemy', Los Angeles Times, 23 July. Available at http://articles.latimes.com/1995-07-23/news/mn-27059_1_bosnianserb. Retrieved 11 January 2012.

${ }^{80}$ Mezedi, I, personal communication.

${ }^{81}$ Kaplan, op cit

82 Weine, op cit, 118-25. 
violence, notably in 'The Morning Hand-Grenade'. ${ }^{83}$ According to Marko Vesovic, ${ }^{84}$ a writer who knew him from university days, 'we had considered his case hopeless as far as literature is concerned'.

Karadzic married Ljiljana Zelen - a Serbian psychiatrist-intraining from an upper-class Sarajevo family-who later practised as a psychoanalyst. They had two children. With suspicious amounts of money at his disposal, he was thought to be a police informer for KOS (the Counterintelligence Agency of the former Yugoslavia) ${ }^{85}$ and was shunned by many.

Karadzic worked at the Djuro Djakovic Adult Education Centre. To further his skills, he had Tavistock Group Therapy training [the Tavistock in London is a highly regarded centre for education and training in different therapies.] He moved to the psychiatric clinic in Kosevo hospital, Sarajevo until 1983, spending 1980 training in psychotherapy at the Zagreb Centre for Mental Health. From 1983 till 1984 he was at the Vozdovac Health Centre in Belgrade. Karadzic continued to engage in activities that would fulfil his grandiose self-image, becoming the psychiatrist for the Sarajevo soccer team, one of the leading teams in Bosnia, and later for the Belgrade Red Star team. Despite subjecting the players to mass hypnosis,

${ }^{83}$ Dekleva, K B and Post, J M (1997), 'Genocide in Bosnia: the case of Dr. Radovan Karadzic', Journal of the American Academy of Psychiatry and the Law, 25, 4, 485-96.

84

http://www.pbs.org/wgbh/pages/frontline/shows/karadzic/inter views/vesovic.html

85

http://www.pbs.org/wgbh/pages/frontline/shows/karadzic/inter views/vesovic.html 
the teams fared no better. ${ }^{86}$

Ever enterprising and needing money for investments and gambling, Karadzic sold fraudulent medical certificates and prescriptions to those who wanted to avoid military service or retire early. On 26 September 1985, he was sentenced to three years in prison and fined for fraud and embezzlement of public funds. He was charged with using a \$100,000 grant meant for farmers to build his own chicken farm in nearby Palé. Karadzic spent only 11 months in prison. He later claimed that he had been a political prisoner and the experience had hardened him, but it is likely the offences were criminal, not political, and his government contacts ensured he did not serve a long sentence. ${ }^{87}$

He returned to psychiatric practice when political pressure to take him back was asserted on the hospital. He worked at the Vozdovac Health Centre in Belgrade in 1987 and that year he presented a paper to a psychotherapy conference analysing a poem about bizarre bodily mutilation. A much-touted book on depression never eventuated. The last record of him working in psychiatry is from February to March 1992 at the Nedjo Zec psychiatric clinic in Kosevo Hospital, Sarajevo. In his last year at the clinic, Karadzic was always accompanied by bodyguards, who caused staff and patients distress by insisting on body searches. Karadzic's availability became increasingly limited, and there were always lines of unhappy patients outside his office. His supervisor, Dr Ismet Ceric, eventually requested he take leave. After he went to Palé in 1992, he did not practise psychiatry again.

\section{Karadzic's possible motivations and mental state}

You want to take Bosnia and Herzegovina down the same highway to hell and suffering that Slovenia and Croatia are

${ }^{86}$ Kaplan, op cit

${ }^{87}$ Kaplan, op cit 
travelling. Do not think that you will not lead Bosnia and Herzegovina into hell, and do not think that you will not perhaps lead the Muslim people into annihilation, because the Muslims cannot defend themselves if there is war-How will you prevent everyone from being killed in Bosnia and Herzegovina? -Dr Radovan Karadzic (October 1991), demonstrating the skills acquired from years of psychotherapy training 88

Little is known about Karadzic's upbringing. His father would undoubtedly have stoked his nationalism, but died when Karadzic was young; his reaction to the death is unknown. His mother spoke glowingly of her son and supported his political goals once he became President. ${ }^{89}$ We know little more of Karadzic the doctor, or why he chose psychiatry. At best he was regarded as marginally competent, indifferent to the concerns of his patients, and corrupt. Dr Ceric described his work as 'ordinary'. ${ }^{90}$ His colleagues, regaled with assertions that he would become a famous psychiatrist or poet, said that he diagnosed everybody with masked depression, provoked psychotic patients, was always late and never completed reports. ${ }^{91}$ When a psychopathic patient with a knife went roaming in the ward, Karadzic retreated to his room, leaving a nurse to disarm and calm him.

Inevitably questions will be raised about Karadzic's mental state. He was reported to drink to excess, spend money and

88 Judah, Tim (1997), The Serbs: History, myth and the destruction of Yugoslavia, New York, Yale University Press, 199.

89 http:/ / www.tnr.com/archive/0698/062998/diarist062998.html.

90

http://www.pbs.org/wgbh/pages/frontline/shows/karadzic/inter views/ceric.htm.

${ }^{91}$ Weine, op cit, 79. 
gamble heavily at casinos. $^{92}$ Dr Ceric said he had psychosomatic symptoms. In springtime and autumn he was depressed and 'a little bit, sometimes euphoric' during summer and winter. Selling medical certificates, gambling and indiscriminate spending are indicative of a grandiose and reckless nature, with strong elements of opportunism. ${ }^{93}$ Vesovic described Karadzic as a psychopath, 'a man without a core'. We cannot exonerate his actions, yet some writers, noting his extreme pronouncements, would consider diagnoses like psychopathy, manic-depression or paranoia. ${ }^{94}$

Dr Ceric wrote that 'at the time there was a joke among our colleagues and our nurses that one day in the future, it's possible that Radovan would come to the clinic early in the morning and say, "Okay I'm back and I'm not guilty of nothing-or everything, everyone else is guilty...the Americans or something...so how about some tea or coffee."'95 Warren Zimmerman, the last American ambassador to Yugoslavia, regarded him as barking mad, obsessed with violence and in need of psychiatric treatment ${ }^{96}$.

What cannot be denied is Karadzic's capacity for gross denial, at times reaching delusional proportions. He alleged that Muslims destroyed the famous National Library, with its irreplaceable cultural treasures, because it was a Christian

92 http:/ / sca.lib.liv.ac.uk/collections/Owen/lists/owencd0.html.

93 Dekleva and Post, op cit

94 Robins, R (1986), 'Paranoid ideation and charismatic leadership', Psychohistory Review, 615-55. Redlich, Fritz (2000), Hitler: Diagnosis of a destructive prophet, New York, Oxford University Press, 334.

95

http://www.pbs.org/wgbh/pages/frontline/shows/karadzic/inter views/ceric.html

96

http://www.pbs.org/wgbh/pages/frontline/shows/karadzic/rado van/impressions.html, retrieved 21 November 2011. 
building. ${ }^{97}$ Far from Sarajevo being under siege by his forces for two years, he blustered that Muslim guns were there to prevent citizens from breaking out of the city. In the face of overwhelming evidence of murderous atrocities by Bosnian Serb forces, he continued to state that there was not one shred of evidence to support these claims and, once again, the atrocities had been carried out by Muslims against their own people. ${ }^{98}$

He never renounced his role as a psychiatrist, even after he assumed the Presidency of the Republika Srpska. One analyst stated that the level of violence of combatants was fanned by Dr Karadzic's 'psychobabble'. ${ }^{99}$ Karadzic's group therapy training influenced his leadership style and choice of terror tactics. Allegations have been made that he witnessed and participated in torture at Bosnian Serb concentration camps. ${ }^{100}$

Karadzic's short reign as President of the Bosnian Serb Republic left an appalling legacy. The full extent of killing and destruction wrought by his forces during the war will never be fully known. The casualties and survivors, many now dispersed around the world as refugees, will suffer for the rest of their lives. Although many aspects of Karadzic's personality remain deeply enigmatic, he displayed an extraordinary degree of reckless opportunism in which the instincts of an extreme gambler were unchallenged by any

97 Cigar, Norman (1995), Genocide in Bosnia, College Station Texas A\&M University Press, 52.

${ }^{98}$ Kaplan, op cit

99 Breo, Dennis (1993), 'Human rights II - Cherif Bassiouni condemns "psychology" of Balkan crimes', Journal of the American Medical Association, 270, 643-44.

100 (1995), 'Witness from hell', De Telegraaf [Amsterdam], May 27, in Deklava and Post, op cit 
restraint or fear of the consequences. His most enduring characteristics are his grandiose self-image, reckless and profligate nature, boundless opportunism and grotesque capacity for self-deception. If nothing else, they disqualify him as a candidate for Hannah Arendt's 'banality of evil'.

\section{Conclusion}

...of all the professions, medicine is one most likely to attract people with high personal anxieties about dying. We become doctors because our ability to cure gives us power over the death of which we are so afraid... - Sherwin Nuland101

The three facets of the medical role are sapiential, authoritarian and charismatic. Sapience, of course, comes from training and experience, while authority is not just implicit but constantly reiterated by the title 'Doctor'. The charismatic role accounts for the fact that doctors are dealing with powerful and mysterious forces. The basis for medical involvement in political abuse goes deep into the psychology of medicine and the personality of the practitioner. At its heart is an extreme grandiosity, a belief that 'treating' (in reality, extirpating) the illness affecting the nation is merely an extension of the ancient and honoured role of treating the sick patient. During the nineteenth century, the belief arose that it was only a question of degree in moving from healing the individual to healing the nation. The murder of other human beings (the emphasis being on those defined as 'the other') was, to some, merely a mental leap from the adjustment required of the doctors to detach themselves from the patients in order to treat them.

In 1937, the Serb philosopher and nationalist Vaso Cubrilovic, who had taken part in the plot to kill the Archduke Franz Ferdinand, anticipated ethnic cleansing in psychological terms. He proposed to remove Albanians from

${ }^{101}$ Nuland, Sherwin (1995), How We Die: Reflections on life's final chapter, 1st Vintage Edition, New York, Vintage, 258. 
Serbian lands by 'the creation of a suitable psychosis', that is, to drive them away by intolerable terror. It is significant that the language used to justify racial genocide was derived from medicine in portraying the enemy in pathological terms. The concept of cleansing or disinfection, particularly since the early 1900s, was intended to facilitate the illusion that the mass murders were intended to promote 'hygiene'. This designation of the victim of eugenic or ethnic genocide as some sort of pathology infecting the society as a whole was a regular part of the process of legitimising massacre as a public health measure by using 'reverse jargon'. ${ }^{102}$

Turkey's Dr Nazim referred to his Armenian victims as dangerous microbes or abscesses; Hitler and his medical acolytes described Jews, inter alia, as parasites, a plague, lice, vermin, cancer, tumours, racial tuberculosis and gangrenous excrescences that had to be eliminated. ${ }^{103}$ Stalin and Beria promoted the term purge to denote the deportation of millions of ethnic Soviet minorities to Siberia, regardless of the mortality. Japanese germ warfare referred to the population in Manchuria as 'logs', whom they used for horrifying experiments; in Rwanda, the Hutu term for Tutsis was 'cockroaches'; Albanian commanders called the Roma 'majutsis', meaning, lower than garbage. ${ }^{104}$ Animalisation and insectification of people, as Rowan Savage shows in his essay here, is the 'simplest' form of dehumanisation, and it is that

102 Blum, Stanton, Sagi and Richter, op cit

103 Biddiss, op cit

104 Savage, Rowan (2006), “'Vermin to be Cleared off the Face of the Earth": Perpetrator representations of genocide victims as animals', in Tatz, Colin, P Arnold and S Tatz (eds) Genocide Perspectives III Essays on the Holocaust and other genocides, Sydney: Brandl and Schlesinger with the Australian Institute for Holocaust and Genocide Studies, 17-53. 
sense of designated enemies as other than human that allows the ideological perpetrators and their minions to justify their actions.

Why do some elements of the psychiatric profession ally themselves with genocide in this way, a way that stridently contradicts every principle of care and healing to which its practitioners are dedicated? Of all the medical sub-disciplines, psychiatry has the most direct link with shamanism, the first specialised role in hunter-gatherer society. The role of the shaman was not just healing the individual but ensuring the harmony of the tribal group by placating the gods, coping with drought or scarcity and predicting the future. In doing so, it became an elite and hereditary priestly group. This tendency continued in the post-Enlightenment decline in religion and its substitution by psychiatry and psychology.

Of all the sub-disciplines, psychiatry was the youngest and the last to achieve professional recognition. By virtue of the terrain in which it operates-the mind-psychiatry is predisposed to overdetermination, making it especially susceptible to utopian ideology or irenic fantasies. The first organiser of the profession, Pinel, driven by the spirit of the French Revolution, sought to change the environment of the patient through 'moral therapy'. Full recognition of the discipline came at the start of the twentieth century from Emil Kraepelin. There is no denying his organisational genius; this, coupled with the development of a rational system of classifying diagnoses, set the profession on track to become a medical speciality.

German psychiatry's greatest asset proved its undoing: academicians perceived themselves as scientists and saw patients as research material. ${ }^{105}$ This was a Faustian pact of the most ominous nature - it laid the seeds of the total moral

105 Engstrom, op cit 
collapse of German psychiatry under the Nazis. ${ }^{106}$ Kraepelin has to take credit for the catastrophic effect of the theory of degeneration on German psychiatry-and ultimately the lowest point in the history of medicine. More than any of his colleagues, Kraepelin had the intelligence and vision to see that degeneration was an ultimately doomed and immoral proposition. By articulating social facts into an implied threat to the collective wellbeing of the nation, ${ }^{107}$ Kraepelin was the chief architect of the psychiatric debauchment that followed. It was no coincidence that Ernst Rüdin, his successor at Heidelberg, was the driving force behind the Nazi euthanasia program. ${ }^{108}$ Another follower, Robert Gaupp, stated in 1938 that Kraepelin's work comprised nothing less than 'the foundation of all Nazi racial hygiene laws'. ${ }^{109}$ English psychiatrist Michael Shepherd described Kraepelin's ideas as proto-fascistic. ${ }^{110}$ When Kraepelin died in 1926, Hitler would have been mostly unknown to him.

Whitely states that psychiatry 'now constitutes an amorphous system of beliefs, behaviours and attitudes whose functions and doctrines are unsettlingly to those held by

106 Hanauske-Abel, Hartmut (1996), 'Not a slippery slope or sudden subversion: German medicine and national socialism in 1933', British Medical Journal, 7 December, 313 (7070), 1453-63.

107 Engstrom, Eric, Burgmair, W and Weber, M M (2002), 'Emil Kraepelin's 'Self-Assessment': clinical autography in historical context', History of Psychiatry, March, 13, 49, 89-119.

108 Pilgrim, David (2008), 'The eugenic legacy in psychology and psychiatry', International Journal of Social Psychiatry, 54, 272-84. 109 Engstrom, Eric J and Weber, M M (2007), 'Making Kraepelin history: A great instauration?', History of Psychiatry, 18, 3, 267-73. 110 Shepherd, Michael (1995), 'Two faces of Emil Kraepelin', British Journal of Psychiatry, August, 167, 2, 174-83. 
conventional religions'.111 Its practitioners undergo years of special training to gain access to knowledge inaccessible to the public (increasingly less so in this age of the internet) allowing them special powers (enforcing treatment). Their terrain, despite constant reiteration that they are now brain-based, is 'the mind', a territory with as little definition as 'the soul' is to the public.

Canonical texts are regarded as being of unshakeable authority but lead to intense (and to the public, largely incomprehensible) disputes. Its ultimate expression, personal psychotherapy, models itself on sacramental involvement and sin confession, establishing a ritual practice akin to regular attendance at Catholic mass. Like any church, psychiatry can be broken down into diverse parts, with different competing schools squabbling over ideology but sharing the same goals and distinguishing itself from opposition, that is, nonprofessional or lay competitors. Like other institutions in the public relations-driven jargon-rich discourse, psychiatric colleges all have 'mission statements'.

Consider, as an example, the Royal Australian and New Zealand College of Psychiatry. ${ }^{112}$ It takes a stand on selected and appropriate public issues, such as child abuse or detention of refugees; yet it shies away from matters that would be seen as falling directly into its bailiwick. At times it appears to take a distinctly moral or censorious approach, sometimes quite legitimately in relation to issues around stigma, for example complaining that the Jim Carey movie Me, Myself and Irene was offensive to mental patients. It is preoccupied with sexual misconduct by doctors (most

111 Whitley, Rob (2008), 'Is psychiatry a religion?', Journal of the Royal Society of Medicine, December, 101, 12, 579-82.

112 It should be stated that in this regard, the RANZCP is little different from its counterparts in the United Kingdom or United States. 
recently, banning delisted psychiatrists from applying to rejoin the College), but has never issued any response to the roles of men like Karadzic and his Serbian colleagues in the Bosnian genocide.

Are psychiatrists as individuals inherently prone to human rights abuse? There is nothing to indicate that most psychiatrists involved in such activities are anything but lawabiding and exemplary citizens. In the former USSR, it would appear that the majority of Soviet psychiatrists were reluctant to participate in state-sanctioned abuse of psychiatric diagnosis and treatment, and 'wriggled out' of such roles as soon as it was politically possible. 113114 The German psychiatrists who led the genocide were not marginal characters, misfits or psychopaths, but some of the most prominent academics. Rüdin and Gaupp, for example, were leaders in the field. Other academics involved in wideranging abuses included Julius Hallervorden, director of the prestigious Kaiser-Wilhelm Institute, who collected brains of euthanasia victims for his neuro-pathological collection, and Carl Schneider, who studied victims before they were murdered and then dissected their brains. Colonel Aubrey Levin, who ran the anti-homosexual Aversion Project in the South African Defence Force, had extreme right-wing views, yet was an otherwise unremarkable personality.

Karadzic, in contrast, was an extremely dubious, if not marginal, character. His work was at best 'ordinary', his attempts to establish himself as an artist (or sporting coach) close to pathetic and he constantly cast around for a role in

113 Bloch, Sidney and Reddaway, P (1997), Psychiatric Terror, New York Basic Books.

114 Chodoff, Paul (2009), 'The abuse of psychiatry', in Bloch, Sidney and Green, S (eds) Psychiatric Ethics, 4th edition, Oxford, Oxford University Press. 
which he could fulfil his grandiose fantasies. Yet Karadzic the genocidaire cannot be separated from Karadzic the psychiatrist. He had no hesitation in shelling his workplace, suggesting that he had internalised the slights of his colleagues and wanted revenge. He thrived on the fighting, was a constant presence at the siege of Sarajevo and used group psychology to plan tactics of terror and ethnic cleansing. That he worked as an alternative therapist when he was in hiding indicates that the genocide was perhaps just another expression, albeit one with the most terrible consequences, of the quest to become the comprehensive 'healer', feasibly an aspiration of genocidal doctors.

In its capacity for overdetermination, does psychiatry have a fatal flaw? This may well be the case. The involvement with eugenics only had consequences in Germany, but led to sterilisation of the mentally ill in countries such as Sweden (as late as 1965) and the United States particularly between the two world wars. At the highwater mark of psychoanalysis in mid-century, American psychiatrists confidently issued nostrums about disturbed youth requiring counselling to solve a range of social problems. For decades, there was suppression of acknowledging child sexual abuse on the basis of Freud's oedipal theory (it was all a fantasy), that swung round to the opposite extreme after 1980 and imprisoned innocent parents on the basis of repressed memories 'discovered' in therapy. Now we see another manifestation of this tendency towards over-zealous social activism, the removal of children from mothers (if not their imprisonment) on the basis of a pseudo-scientific and unproven theory known as Munchausen's Syndrome by Proxy.

It has to be accepted that, with the best intentions in the world, the practise of psychiatry can lend itself at intervals to a view of society that can be described, variously, as patronising, paternalistic, Manichean and all-encompassing. In this scenario, the outcome is inevitable. From the individual to the profession, there arise those who ally themselves with the state to use their skills to abuse, if not 
destroy, other groups of people, driven by an inexorable sense of rectitude that may, in some cases at least, overlie a surging torrent of rage that led them to the profession in the first case.

As a result of atrocities committed during the Bosnian Civil War of 1992-1995, Karadzic stands indicted as a suspected war criminal for crimes against humanity and genocide, the first doctor so indicted since the Nuremberg Doctors' Trial in 1946. These crimes include killing 68 civilians in the shelling of the Markale marketplace on 5 February 1994, the use of 248 United Nations peacekeepers as human shields, and the murder of up to 7,500 people under UN protection at Srebrenica.

In 1993, the American Psychiatric Association passed a motion condemning Karadzic for 'brutal and inhumane actions'. The condemnation was issued with 'particular offence, urgency and horror because, by membership and training, Dr Karadzic claims membership in our profession'. ${ }^{115}$

Psychiatrists, alongside other medical and mental health professionals, have wide reaching moral responsibility. Prominent psychiatrist Thomas Szasz made the point quite bluntly: 'It is the moral duty of psychologists and psychiatrists to safeguard the dignity and liberty of people generally, and, in particular those with whom they work. If instead they take professional advantage of the imprisoned status of incarcerated individuals or populations, they are, in my opinion, criminals. '116

115

http://www.psych.org/Departments/EDU/Library/APAOfficialD ocumentsandRelated/PositionStatements/199301.aspx 116 Szasz, Thomas Stephen (1979), The Theology of Medicine: The political-philosophical foundations of medical ethics, Oxford, Oxford 
Regrettably, the evidence thus far suggests that doctors, regardless of prestige, ability, qualification or training, are amongst the most willing accomplices of state abuse. They will play a leading role in perpetuating the system, support and participate in state abuse and, where circumstances permit, willingly accede to leadership of repressive regimes. What cannot be doubted is that this phenomenon is a beginning, not an end, and will undoubtedly recur in future.

We kill everybody, my dear. Some with bullets, some with words, and everybody with our deeds. We drive people into their graves, and neither see it nor feel it. -Maxim Gorky in Enemies 117

\section{Acknowledgements}

Robert M Kaplan and Garry Walter thank Dr Nerissa Soh for her assistance with sourcing material, and Vicken Babkenian and Anabell St Vincent for their advice and encouragement.

University Press, 52.

117 Enemies was first published in 1906 (an English version by Kitty Hunter-Blair and Jeremy Brooks, published 1972 by E Methuen in London). 